\title{
RESEARCH ARTICLE Effects of Mixed Sowing of Chinese Milk Vetch (Astragalus sinicus L.) and Rape on Rice Yield and Soil Physical and Chemical Properties
}

\author{
Qiliang Hu Binjuan Yang Na Li Ning Liu Shujiang Guo Guoqin Huang* \\ Research Center on Ecological Sciences, Jiangxi Agricultural University, Nanchang, Jiangxi, 330045, China
}

\begin{abstract}
In order to explore the effects of Chinese milk vetch and rape mixed sowing on rice yield and soil fertility, and select the best planting mode, five different ratios of Chinese milk vetch and rape mixed sowing were designed to study the effects of different ratios on rice yield, soil physicochemical properties and soil fertility in $0-10 \mathrm{~cm}, 10-20$ $\mathrm{cm}$ and 20-30 cm layers. Grey correlation analysis of soil nutrients and yield was carried out by using the grey system theory. The influence of different soil layers on soil chemical properties was greater than physical properties. The effect on shallow soil is greater than that on deep soil. Mixed sowing of Chinese milk vetch and rape improved soil comprehensive fertility in all soil layers, and rice yield was the highest in the $2 \mathrm{M} 2 \mathrm{R}$ treatment. $\mathrm{pH}$ value had the greatest effect on actual rice yield, followed by available potassium. Therefore, mixed sowing of Chinese milk vetch and rape could significantly increase the yield of early rice and soil nutrient content, and the pattern of " $1 / 2$ Chinese milk vetch $+1 / 2$ rape-early rice-late rice" had the best effect.
\end{abstract}

Keywords: Mixed sowing of Chinese milk vetch and rape; Rice yield; Comprehensive fertility; Grey correlation method

\section{Introduction}

The paddy field triple cropping system of planting green fertilizer in winter in double cropping rice field is a traditional planting mode in south China. As early as more than 3,000 years ago, China used green fertilizer to control weeds and cultivate land and fertilizer ${ }^{[1]}$, and China has the largest planting area of green fertilizer in the world. Chinese milk vetch is a biennial legume crop having symbiotic nitrogen fixing bacteria with its root can fix nitrogen in the air, and average nitrogen fixation is 75$120 \mathrm{~kg} \cdot \mathrm{hm}^{-2}$ in the peak flowering stage. However, due to the shortage of Chinese milk vetch seed resources, high price, and the low $\mathrm{C} / \mathrm{N}$ of Chinese milk vetch, it is not beneficial to the accumulation of nitrogen and organic matter in soil, which restricts its promotion and application ${ }^{[2]}$. Rape is the traditional cruciferous green fertilizer

\footnotetext{
*Corresponding Author:

Guoqing Huang,

Research Center on Ecological Sciences, Jiangxi Agricultural University, Nanchang, Jiangxi, 330045, China;

Email:hgqjxes@sina.com
}

Received: 12 January 2022; Received in revised form: 15 February 2022; Accepted: 18 February 2022; Published: 4 March 2022

Citation: Hu, Q.L., Yang, B.J., Li, N., et al., 2022. Effects of Mixed Sowing of Chinese Milk Vetch (Astragalus sinicus L.) and Rape on Rice Yield and Soil Physical and Chemical Properties. Research on World Agricultural Economy. $3(1), 483$. http://dx.doi.org/10.36956/rwae.v3i1.483 
in China, which has the advantages of wide range of adaptation, easy seed acquisition, low cost, high fertilizer efficiency, conducive to the accumulation of organic matter, and can activate phosphorus and potassium in the soil. Root exudates can stimulate nitrogen-fixing bacteria. Therefore, mixed sowing of Chinese vetch and rape can make full use of light and heat resources in over ground and water and nutrient resources in underground part ${ }^{[3]}$. Huang showed that, compared with the winter fallow treatment, the long-term return of Chinese milk vetch and rape to the field as green fertilizer could increase rice yield, reduce yield variation coefficient and increase the sustainability index of rice yield ${ }^{[4]}$. Gao ${ }^{[5]}$ showed that returning green fertilizer to the field can promote rice yield, improve soil organic matter content and maintain soil nitrogen supply, which is a tillage system to maintain high and stable yield and sustainable development of rice. Deng ${ }^{[6]}$ showed that winter rapeseed had obvious effects on improving soil physical and chemical properties, reducing soil bulk density, and increasing soil available potassium and organic matter contents, and the subsequent rice production increased significantly. There are many studies on the effects of single sowing of green fertilizer on rice yield and soil physicochemical properties, but there are few studies and comprehensive analysis on the effects of different mixed sowing ratios of Chinese milk vetch and rape on subsequent crops and soil. Therefore, in this paper, the actual rice yield and the comprehensive fertility index (IFI) of different soil layers under the mixed sowing of Chinese milk vetch and rape were studied, and the main soil chemical properties affecting the rice yield were analyzed by using the grey relational system theory, providing a scientific theoretical basis for the mixed sowing of green fertilizer technology in double cropping rice field.

\section{Materials and Methods}

\subsection{Experimental Site Overview}

The experiment was conducted from September 2017 to present in the rice experimental field $\left(28^{\circ} 46^{\prime} \mathrm{N}, 115^{\circ}\right.$ $\left.55^{\prime} \mathrm{E}\right)$ in the Science park of Jiangxi Agricultural University. The experimental site belongs to the subtropical monsoon humid climate, with the annual total solar radiation of $4.79 \times 1013 \mathrm{~J} \cdot \mathrm{hm}^{-2}$, the annual sunshine duration of $1852 \mathrm{~h}$, the annual effective accumulated temperature $\geq 0$ ${ }^{\circ} \mathrm{C}$ of $6450{ }^{\circ} \mathrm{C}$, the annual precipitation of $1665.7 \mathrm{~mm}$, and the annual average temperature between $17.1{ }^{\circ} \mathrm{C}$ and 17.8 ${ }^{\circ} \mathrm{C}$. The soil used in the experiment is red clay developed in the Quaternary, which is a typical subtropical red soil distribution area. At the beginning of the experiment, the content of organic matter was $34.93 \mathrm{~g} \cdot \mathrm{kg}^{-1}$, total nitrogen was $2.00 \mathrm{mg} \cdot \mathrm{kg}^{-1}$, available phosphorus was 15.58 $\mathrm{mg} \cdot \mathrm{kg}^{-1}$, available potassium was $41.73 \mathrm{mg} \cdot \mathrm{kg}^{-1}$ and $\mathrm{pH}$ was 4.98 .

\subsection{Experimental Design}

The experiment consisted of five treatments: (1) M $\left(\mathrm{CK}_{1}\right)$, single seeding of Chinese milk vetch - early ricelate rice; (2) treatment 3M1R, 3/4 Chinese milk vetch $+1 / 4$ rape-early rice-late rice; (3) treatment $2 \mathrm{M} 2 \mathrm{R}, 1 / 2$ Chinese milk vetch $+1 / 2$ rape-early rice-late rice; (4) treatment 1M3R, 1/4 Chinese milk vetch $+3 / 4$ rape-early rice-late rice; (5) Treatment $\mathrm{R}\left(\mathrm{CK}_{2}\right)$, single sowing rape - early rice-late rice. The sowing amount was $22.5 \mathrm{~kg} \cdot \mathrm{hm}^{-2}$ for Chinese milk vetch and $7.5 \mathrm{~kg} \bullet \mathrm{hm}^{-2}$ for rape. Each treatment was repeated for 3 times, with a total of 15 plots with an area of $16.5 \mathrm{~m}^{2}(5.5 \mathrm{~m} \times 3 \mathrm{~m})$. The plots were separated by cement ridges $30 \mathrm{~cm}$ high. Before the experiment, soil fertility in each plot was uniform. Both sides are provided with a protection line, the width of the protection line is $30 \mathrm{~cm}$.

\subsection{Sample Collection and Determination}

\subsubsection{Rice Yield Measurement}

At the late rice maturity stage, 50 stump were surveyed in each plot as the basis for effective panicle calculation, and 3 stump of representative rice plants were randomly selected in each plot by average method, and then used as seed test materials after natural air drying. The mass of 1000 grains was measured with $1 / 1000$ analytical balance; each single cell as the actual yield.

\subsubsection{Soil Nutrient Determination}

One day after rice harvesting, each plot was divided into $0-10 \mathrm{~cm}, 10-20 \mathrm{~cm}$ and $20-30 \mathrm{~cm}$ layers according to the "5-point sampling method", and the tillage layer soil was evenly mixed, air-dried naturally, impurities removed and sieving, and soil nutrients were measured: soil $\mathrm{pH}$ was measured by $\mathrm{pH}$ meter; The content of organic matter was determined by external heating method of potassium dichromate and concentrated sulfuric acid; The total nitrogen content was determined by semi micro open nitrogen determination method; The content of available phosphorus was determined by $\mathrm{NaHCO}_{3}$ extraction and molybdenum-antimony resistance colorimetry; The content of available potassium was extracted by $\mathrm{NH}_{4} \mathrm{OAc}$ and flame photometry ${ }^{[7]}$

\subsection{Data Calculatio}

Soil Integrated Fertility Index (IFI): Nemerow index method ${ }^{[8]}$ was used to evaluate the soil fertility quality un- 
der each treatment. In this paper, soil $\mathrm{pH}$, organic matter, total nitrogen, available phosphorus and available potassium were selected as fertility indexes to calculate fertility coefficient, and the modified Nemerow formula was used to calculate soil comprehensive fertility index.

(1) Calculation of fertility index IFI:

$$
\text { IFIi }\left\{\begin{array}{cc}
\mathrm{X} / \mathrm{Xa} & \mathrm{X} \leq \mathrm{Xa} \\
1+(\mathrm{X}-\mathrm{Xa}) /(\mathrm{Xc}-\mathrm{Xa}) & \mathrm{Xa}<X \leq X c \\
2+(\mathrm{X}-\mathrm{Xc}) /(\mathrm{Xp}-\mathrm{Xc}) & \mathrm{Xc}<X \leq X p \\
3 & \mathrm{X}>X p
\end{array}\right.
$$

Where, $\mathrm{IFI}_{\mathrm{i}}$ : fertility coefficient, $\mathrm{X}$ : measured value of this attribute; $\mathrm{Xa}$ and $\mathrm{Xp}$ grading standards lower and upper limit, Xc: between the upper and lower limits of grading standards (Table 1).

Table 1. Standard values of soil attribute classification

\begin{tabular}{cccccc}
\hline classification & $\mathrm{pH}$ & $\begin{array}{c}\text { Organic } \\
\text { matte } \\
\left(\mathrm{g} \cdot \mathrm{kg}^{-1}\right)\end{array}$ & $\begin{array}{c}\text { Total } \\
\text { nitrogen } \\
\left(\mathrm{g} \cdot \mathrm{kg}^{-1}\right)\end{array}$ & $\begin{array}{c}\text { Available } \\
\text { phosphorus } \\
\left(\mathrm{mg} \cdot \mathrm{kg}^{-1}\right)\end{array}$ & $\begin{array}{c}\text { Available } \\
\text { potassium } \\
\left(\mathrm{mg} \cdot \mathrm{kg}^{-1}\right)\end{array}$ \\
\hline $\mathrm{Xa}$ & 4.5 & 20 & 1 & 10 & 100 \\
$\mathrm{Xc}$ & 6.5 & 30 & 1.5 & 20 & 150 \\
$\mathrm{Xp}$ & 8.5 & 40 & 2 & 40 & 200 \\
\hline
\end{tabular}

(2) Calculation of comprehensive soil fertility index IFI:

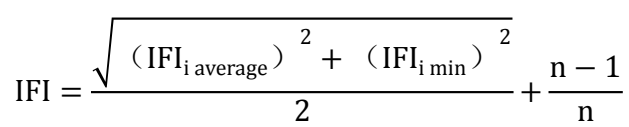

Where, $\mathrm{IFI}_{\mathrm{i} \text { average }}$ and $\mathrm{IFI}_{\mathrm{i} \text { minimum }}$ are the mean and minimum values of soil fertility of each attribute; $n$ is the number of evaluation indicators.

Grey correlation degree calculation of soil nutrients. Different soil nutrient indexes were represented by X, different plots were represented by $\mathrm{K}$, and the actual rice yield was taken as the reference series $\mathrm{X}_{0}$. Based on the grey relational system theory, the range normalization method is used to standardize the data ${ }^{[9,10]}$. The specific calculation formula is as follows:
Correlation formula:

$\varepsilon_{\mathrm{i}(\mathrm{k})}=\frac{\operatorname{minmin}|x o(k)-x i(k)|+\rho \operatorname{maxmax}|x o(k)-x i(k)|}{|x o(k)-x i(k)|-\rho \operatorname{maxmax}|x o(k)-x i(k)|}$

Equal weight correlation: $\mathrm{R}_{\mathrm{i}}=\frac{1}{\mathrm{~N}} \sum_{\mathrm{K}=1}^{\mathrm{N}} \varepsilon_{\mathrm{i}(\mathrm{k})}$

Type: $\operatorname{minmin}|x o(k)-x i(k)|$ for the secondary minimum differential, maxmax $|x o(k)-x i(k)|$ for maximum differential secondary, is distinguish coefficient, the value range is 0 to 1 , the $\mathrm{N}$ number of samples.

\subsection{Data Analysis}

Excel2019 was used for statistical processing, SPSS20.0 was used for one-way analysis of variance, and Origin 2018 was used for icon making.

\section{Results}

\subsection{Effects of Different Mixing Ratios of Chinese Milk Vetch and Rape on Rice Yield}

As can be seen from Table 2, the effects of different treatments on effective panicle number, 1000-grain weight and actual yield of rice under different proportions of Chinese milk vetch and rape were significant. There was no significant difference in grain number per panicle and seed setting rate among all treatments. In terms of effective panicle number, 1000-grain weight and actual yield, treatment $2 \mathrm{M} 2 \mathrm{R}$ had the best performance, and the effective panicle number of treatment $2 \mathrm{M} 2 \mathrm{R}$ was significantly different from that of two monocultures $(P<0.05)$, which was $15.18-16.18 \%$ higher than that of two monocultures. The 1000 -grain weight of treatment $2 \mathrm{M} 2 \mathrm{R}$ was significantly higher than that of treatment $\mathrm{R}$ by $8.40 \%(\mathrm{P}<0.05)$. Treatment 2M2R $\left(9073.11 \mathrm{~kg} \bullet \mathrm{hm}^{-2}\right)$ was significantly higher than that of treatment $\mathrm{R}\left(7594.76 \mathrm{~kg} \cdot \mathrm{hm}^{-2}\right)$ by $19.47 \%$ $(P<0.05)$. Therefore, mixed sowing of Chinese milk vetch and rape could significantly increase rice yield compared with monoculture treatment.

Table 2. Effects of mixed sowing Chinese milk vetch and rape on rice yield and its components

\begin{tabular}{ccccccc}
\hline $\begin{array}{c}\text { Planting } \\
\text { season }\end{array}$ & Treatment & $\begin{array}{c}\text { Effective panicle number/ } \\
\left(\times 10^{4} \cdot \mathrm{hm}^{-2}\right)\end{array}$ & $\begin{array}{c}\text { Grain number per } \\
\text { spike }\end{array}$ & $\begin{array}{c}\text { Seed setting } \\
\text { rate } \%\end{array}$ & 1000 grain weight/g & $\begin{array}{c}\text { Actural production/ } \\
\left(\mathrm{kg} \cdot \mathrm{hm}^{-2}\right)\end{array}$ \\
\hline \multirow{2}{*}{ late rice } & $\mathrm{M}\left(\mathrm{CK}_{1}\right)$ & $212.31 \pm 8.96 \mathrm{~b}$ & $206.43 \pm 13.20 \mathrm{a}$ & $71.85 \% \pm 2.37 \mathrm{a}$ & $23.49 \pm 0.57 \mathrm{ab}$ & $7941.89 \pm 541.39 \mathrm{ab}$ \\
& $3 \mathrm{M} 1 \mathrm{R}$ & $232.93 \pm 8.08 \mathrm{ab}$ & $203.12 \pm 8.98 \mathrm{a}$ & $74.34 \% \pm 1.89 \mathrm{a}$ & $24.24 \pm 0.50 \mathrm{ab}$ & $8376.47 \pm 366.71 \mathrm{ab}$ \\
& $2 \mathrm{M} 2 \mathrm{R}$ & $244.54 \pm 9.49 \mathrm{a}$ & $209.65 \pm 12.61 \mathrm{a}$ & $76.24 \% \pm 2.72 \mathrm{a}$ & $25.04 \pm 0.47 \mathrm{a}$ & $9073.11 \pm 375.37 \mathrm{a}$ \\
& $1 \mathrm{M} 3 \mathrm{R}$ & $225.35 \pm 7.93 \mathrm{ab}$ & $208.14 \pm 7.38 \mathrm{a}$ & $74.29 \% \pm 2.01 \mathrm{a}$ & $23.34 \pm 0.46 \mathrm{~b}$ & $8209.09 \pm 249.75 \mathrm{ab}$ \\
& $\mathrm{R}\left(\mathrm{CK}_{2}\right)$ & $210.49 \pm 6.86 \mathrm{~b}$ & $214.39 \pm 7.55 \mathrm{a}$ & $73.87 \% \pm 2.78 \mathrm{a}$ & $23.10 \pm 0.37 \mathrm{~b}$ & $7594.76 \pm 173.14 \mathrm{~b}$ \\
\hline
\end{tabular}

Note: Data are mean of 3 replicates \pm standard error; Different letters in the same column indicate a significant difference of $5 \%$. 
3.2 Effects of Different Mixing Ratios of Chinese Milk Vetch and Rape on Soil Physical Properties

As shown in Figure 1, at the late rice maturity stage in 2020 , the water content and bulk density of each treatment in different soil layers were significantly different, but the difference between each treatment in the same soil layer was not significant. With the deepening of soil layer, soil moisture content decreased and bulk density increased. In $0-30 \mathrm{~cm}$ tilled soil, soil physical properties changed faster with the deepening of soil layer. There were significant differences in $0-10 \mathrm{~cm}$ soil layer. There was no significant difference in bulk density between the treatments in 10-20 $\mathrm{cm}$ and 20-30 cm soil layers, but there was a significant difference between control $\mathrm{R}$ and other treatments in the depth of $10-20 \mathrm{~cm}$ soil layer $(P<0.05)$.

\subsection{Effects of Different Mixing Ratios of Chinese Milk Vetch and Rape on Soil Chemical Properties}
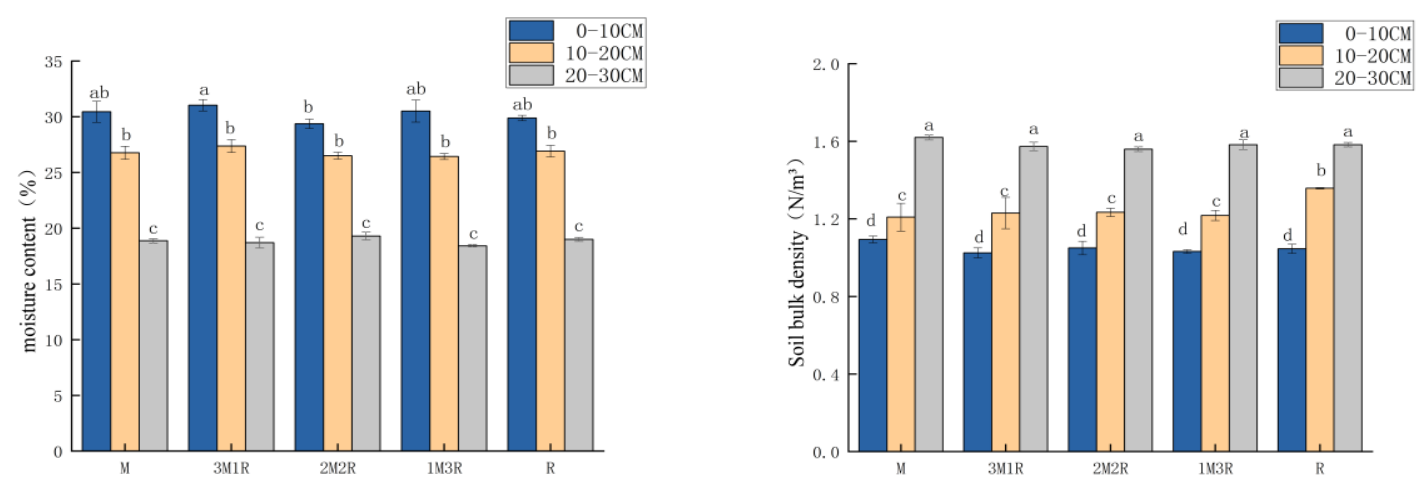

Figure 1. Effects of mixed sowing of Chinese milk vetch and rape on water content and bulk density in different soil layers

Table 3. Effects of mixed sowing of Chinese milk vetch and rape on soil nutrients and fertility

\begin{tabular}{|c|c|c|c|c|c|c|}
\hline Depth & Treatment & $\mathrm{pH}$ & $\begin{array}{l}\text { Organic matter } \\
\left(\mathrm{g} \cdot \mathrm{kg}^{-1}\right)\end{array}$ & $\begin{array}{l}\text { Total nitrogen } \\
\left(\mathrm{g} \cdot \mathrm{kg}^{-1}\right)\end{array}$ & $\begin{array}{l}\text { Available phosphorus } \\
\qquad\left(\mathrm{mg} \cdot \mathrm{kg}^{-1}\right)\end{array}$ & $\begin{array}{c}\text { Available potassium } \\
\left(\mathrm{mg} \cdot \mathrm{kg}^{-1}\right)\end{array}$ \\
\hline \multirow[t]{5}{*}{$0-10 \mathrm{~cm}$} & $\mathrm{M}\left(\mathrm{CK}_{1}\right)$ & $4.55 \pm 0.03 \mathrm{c}$ & $31.98 \pm 0.33 \mathrm{a}$ & $2.02 \pm 0.02 \mathrm{a}$ & $16.26 \pm 1.32 \mathrm{abcd}$ & $61.00 \pm 10.58 \mathrm{abc}$ \\
\hline & $3 \mathrm{M} 1 \mathrm{R}$ & $4.54 \pm 0.07 \mathrm{c}$ & $33.29 \pm 0.15 \mathrm{a}$ & $2.13 \pm 0.02 \mathrm{a}$ & $18.72 \pm 1.94 \mathrm{ab}$ & $69.67 \pm 5.24 \mathrm{a}$ \\
\hline & $2 \mathrm{M} 2 \mathrm{R}$ & $4.56 \pm 0.04 \mathrm{c}$ & $33.04 \pm 0.38 \mathrm{a}$ & $2.16 \pm 0.01 \mathrm{a}$ & $19.54 \pm 1.13 \mathrm{a}$ & $73.33 \pm 2.40 \mathrm{ab}$ \\
\hline & $1 \mathrm{M} 3 \mathrm{R}$ & $4.52 \pm 0.03 \mathrm{c}$ & $31.58 \pm 0.83 \mathrm{a}$ & $2.04 \pm 0.05 \mathrm{a}$ & $17.33 \pm 2.97 \mathrm{abc}$ & $64.00 \pm 3.61 \mathrm{abc}$ \\
\hline & $\mathrm{R}\left(\mathrm{CK}_{2}\right)$ & $4.51 \pm 0.04 \mathrm{c}$ & $31.71 \pm 0.36 \mathrm{a}$ & $2.05 \pm 0.01 \mathrm{a}$ & $16.88 \pm 0.93 \mathrm{abc}$ & $62.67 \pm 1.20 \mathrm{ab}$ \\
\hline \multirow[t]{5}{*}{$10-20 \mathrm{~cm}$} & $\mathrm{M}\left(\mathrm{CK}_{1}\right)$ & $4.69 \pm 0.05 b$ & $21.98 \pm 1.30 \mathrm{~b}$ & $1.45 \pm 0.09 \mathrm{~b}$ & $14.13 \pm 3.12 \mathrm{abcde}$ & $47.33 \pm 1.20 \mathrm{~b}$ \\
\hline & $3 \mathrm{M} 1 \mathrm{R}$ & $4.73 \pm 0.06 \mathrm{~b}$ & $24.35 \pm 1.24 \mathrm{~b}$ & $1.61 \pm 0.11 \mathrm{~b}$ & $12.07 \pm 3.07 \mathrm{abcde}$ & $46.67 \pm 3.71 \mathrm{~b}$ \\
\hline & $2 \mathrm{M} 2 \mathrm{R}$ & $4.73 \pm 0.03 \mathrm{~b}$ & $22.61 \pm 1.47 \mathrm{~b}$ & $1.61 \pm 0.23 b$ & $13.08 \pm 3.20 \mathrm{abcde}$ & $50.00 \pm 10.00 \mathrm{~b}$ \\
\hline & $1 \mathrm{M} 3 \mathrm{R}$ & $4.73 \pm 0.04 b$ & $23.74 \pm 0.28 b$ & $1.58 \pm 0.04 \mathrm{~b}$ & $11.90 \pm 0.99 \mathrm{bcde}$ & $51.00 \pm 7.55 \mathrm{~b}$ \\
\hline & $\mathrm{R}\left(\mathrm{CK}_{2}\right)$ & $4.77 \pm 0.05 b$ & $22.42 \pm 2.20 \mathrm{~b}$ & $1.47 \pm 0.13 \mathrm{~b}$ & $13.47 \pm 1.11 \mathrm{abcd}$ & $58.67 \pm 7.80 \mathrm{bc}$ \\
\hline \multirow[t]{5}{*}{$20-30 \mathrm{~cm}$} & $\mathrm{M}\left(\mathrm{CK}_{1}\right)$ & $5.59 \pm 0.04 \mathrm{a}$ & $13.60 \pm 1.36 \mathrm{c}$ & $0.95 \pm 0.08 \mathrm{c}$ & $7.72 \pm 0.22 \mathrm{e}$ & $49.67 \pm 4.33 b$ \\
\hline & 3M1R & $5.55 \pm 0.02 \mathrm{a}$ & $16.49 \pm 1.06 \mathrm{c}$ & $0.91 \pm 0.10 \mathrm{c}$ & $9.30 \pm 1.65 \mathrm{de}$ & $46.00 \pm 4.36 \mathrm{~b}$ \\
\hline & $2 \mathrm{M} 2 \mathrm{R}$ & $5.57 \pm 0.02 \mathrm{a}$ & $16.02 \pm 1.54 \mathrm{c}$ & $0.82 \pm 0.11 \mathrm{c}$ & $9.74 \pm 2.44 \mathrm{de}$ & $51.00 \pm 1.73 b$ \\
\hline & $1 \mathrm{M} 3 \mathrm{R}$ & $5.52 \pm 0.02 \mathrm{a}$ & $16.63 \pm 0.76 \mathrm{c}$ & $0.90 \pm 0.02 \mathrm{c}$ & $11.85 \pm 2.32 \mathrm{bcde}$ & $47.00 \pm 5.29 \mathrm{~b}$ \\
\hline & $\mathrm{R}\left(\mathrm{CK}_{2}\right)$ & $5.55 \pm 0.02 \mathrm{a}$ & $13.99 \pm 0.96 \mathrm{c}$ & $0.77 \pm 0.04 \mathrm{c}$ & $10.40 \pm 1.48 \mathrm{cde}$ & $46.67 \pm 2.40 \mathrm{~b}$ \\
\hline
\end{tabular}




\subsection{Effects of Mixed Sowing of Different Proportions of Chinese Milk Vetch and Rape on Soil Chemical Properties}

Figure 2 shows the comprehensive soil fertility index (IFI) at the late rice maturity stage in 2020. As shown in Figure 2, there were significant differences in soil fertility among different soil layers under different treatments $(P<0.05)$, but no significant differences among different treatments in the same soil layer $(P>0.05)$. In $0-10 \mathrm{~cm}$ layer, 2M2R was the highest and $\mathrm{M}$ was the lowest. In 10$20 \mathrm{~cm}$ layer, treatment $3 \mathrm{M} 1 \mathrm{R}$ was the highest and treatment $\mathrm{M}$ was the lowest. At $20-30 \mathrm{~cm}$, treatment $1 \mathrm{M} 3 \mathrm{R}$ was the highest, and treatment $\mathrm{M}$ and $\mathrm{R}$ were the lowest. In general, mixed sowing of Chinese milk vetch and rape had a great effect on the comprehensive index of shallow soil fertility, and the IFI index of mixed sowing was higher than that of single sowing.

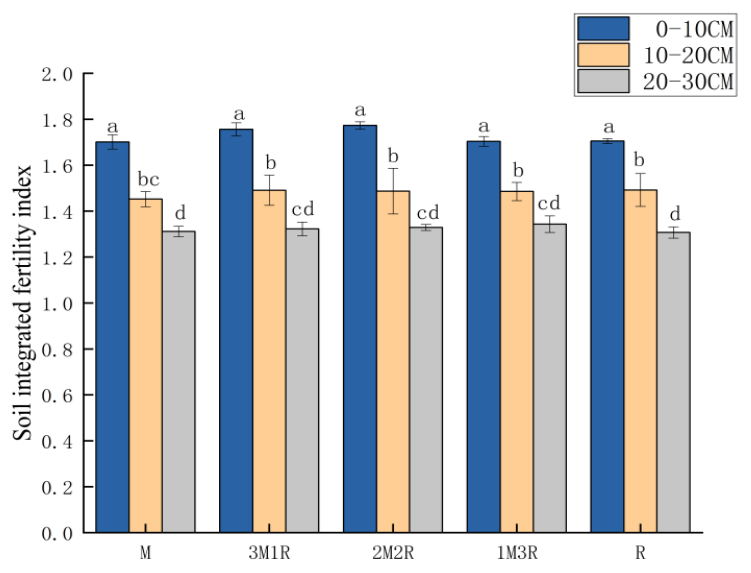

Figure 2. Comprehensive soil fertility index under different treatments

\subsection{Grey Correlation Analysis of Rice Yield and Soil Fertility under Different Mixed-planting Ratios}

According to the requirements of grey system theory, the grey correlation degree between soil nutrient indexes and actual rice yield was analyzed, and $\rho$ was 0.5 . The higher the score of the equal-weight correlation coefficient, the greater the correlation between the index and the actual rice yield. It can be seen from Figure 3 that the correlation degree of all indexes on yield is as follows: $\mathrm{pH}$ $(0.7332)>$ available potassium $(0.6957)>$ organic matter $(0.6785)>$ total nitrogen $(0.6562)>$ available phosphorus $(0.6561)$. Gray correlation analysis of soil nutrients and rice yield can explore the relationship between rice yield and soil nutrients, and help clarify the nutrient factors affecting rice yield. In this test field, $\mathrm{pH}$ is the biggest fac- tor affecting rice yield, followed by available potassium. Increasing soil $\mathrm{pH}$ and applying potassium fertilizer can greatly improve rice yield.

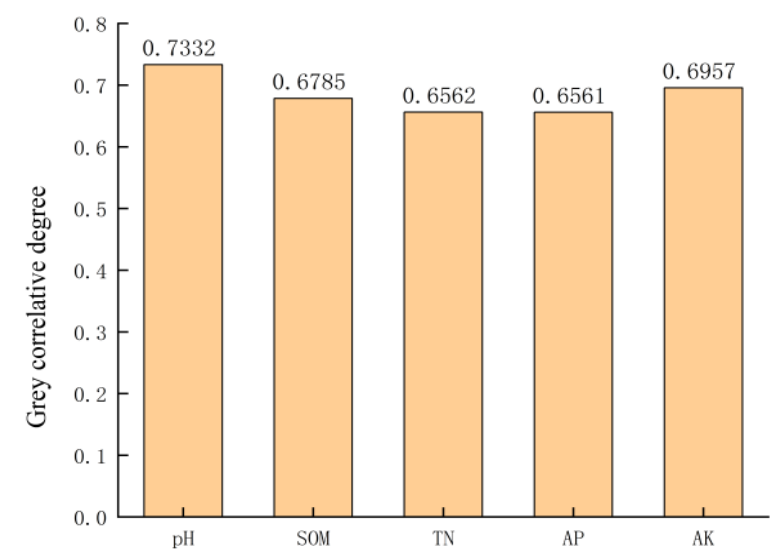

Figure 3. Equal-weight correlation degree and ranking of soil nutrient indexes

\section{Discussion}

\subsection{Effects of Different Mixing Ratio on Rice Yield}

By turning green fertilizer into soil, organic fertilizer is formed and released into paddy soil, which not only improves the utilization rate of fertilizer, but also ensures the need for fertilizer at all stages of rice growth and improves rice yield ${ }^{[1]}$. Increased application of organic materials can significantly improve crop yield ${ }^{[12]}$. Zeng ${ }^{[13]}$ showed that the effective panicle number, solid grain number and 1000-grain weight of rice under milk vetch mulching were increased, and the number of grains per panicle and seed setting rate of rice under rape straw returning were increased ${ }^{[14]}$. The results of this study showed that the effective panicle number of $2 \mathrm{M} 2 \mathrm{R}$ was $15.18-16.18 \%$ higher that of monoculture, and the actual rice yield was $14.24-19.47 \%$ higher than that of monoculture. Green fertilizer returning could increase rice yield by improving the effective panicle number, which was consistent with the research results of Li Ping ${ }^{[15]}$.

\subsection{Effects of Different Mixing Ratio on Soil Physical and Chemical Properties}

Winter planting of green manure in double cropping rice fields not only improves surface water content, enhances soil permeability, and achieves the effect of conserving soil moisture, but also reduces soil bulk density and optimizes soil structure by turning and returning green manure to the field ${ }^{[16]}$. The results of this study showed that the effect of Chinese milk vetch monoculture and mixed sowing of Chinese milk vetch and rape on soil bulk 
density reduction was better than that of rape monoculture. Returning green manure to the field as organic matter can increase rich nutrients for the soil and transform insoluble nutrients in the soil ${ }^{[17]}$. Huang ${ }^{[18]}$ showed that the mixed sowing of Chinese milk vetch and rape could increase the contents of soil organic matter, insoluble nutrient transformation, available phosphorus and available potassium. The results of this study showed that under the green fertilizer and double cropping rice planting mode, the mixed sowing treatments of Chinese milk vetch and rape improved the soil nutrients in different layers, and each treatment had a great impact on the soil nutrients in $0-10 \mathrm{~cm}$ layer, in which the available phosphorus and available potassium were the most obvious. The available phosphorus content in treatment 2M2R was the highest, and the available potassium content in treatment $3 \mathrm{M} 1 \mathrm{R}$ was the highest. In 0-30 cm soil layer, there were significant differences in comprehensive soil fertility of each layer, indicating that soil depth was closely related to soil fertility.

Mixed green manure increased the soil comprehensive fertility index (IFI) the most, which might be because Chinese milk vetch was a leguminous crop and atmospheric nitrogen during its growth. Rape has the function of activating insoluble nutrients, and the biomass of mixed sowing treatment is larger, green manure rot explains the release of a large amount of nitrogen, phosphorus, potassium, so improve the comprehensive soil fertility. There was no obvious difference among all treatments, which may be due to the lack of test years. The specific content of soil nutrients increased by mixed sowing of different proportions of Chinese vetch rape needs to be verified by long-term positioning test. Soil fertility reflects the degree of soil fertility, which is the basis of productivity ${ }^{[19,20]}$. The results of this study showed that different soil nutrients had different effects on rice yield, and the most important factor affecting rice yield was $\mathrm{pH}$, followed by available potassium. Therefore, selecting a suitable mixture ratio of Chinese milk vetch and rape can increase rice yield.

\section{Conclusions}

In conclusion, the mixed planting pattern of Chinese milk veg and rape can better improve shallow soil fertility and increase rice yield and components. In this experiment, $11.25 \mathrm{~kg} \cdot \mathrm{hm}^{-2}$ Chinese milk vetch $+3.75 \mathrm{~kg} \cdot \mathrm{hm}^{-2}$ rape-early-rice-late rice had the best effect, which was a new green fertilizer planting mode and crop rotation mode in south China, and had a very good application prospect.

\section{Funding}

This research was funded by the National Research Foundation of China (4166107); National Key Research and Development Program of China (2016YFD0300208); Key disciplines (construction) of ecology in the $13^{\text {th }}$ FiveY ear Plan of Jiangxi Agricultural University.

\section{Conflict of Interest}

The authors declare no conflict of interest.

\section{References}

[1] Li, Z., Lian, X., Wang, W., et al., 2013. Research progress of green fertilizer in China. Pratacultural Science. 30(7), 1135-1140.

[2] Jiang, M., Li, Y., Jiang, J., et al., 2020. Effects of different sowing dates and Ratios on biomass and nutrient accumulation of green fertilizer in mixed sowing of Rapeseed and Chinese milk vetch. Shanghai Agricultural Science and Technology. 2, 13-15.

[3] Zhou, K., Xing, J., Bo, Y., et al., 2005. Physiological and ecological effects of mixed cropping system between Rapeseed and Chinese milk vetch. Chinese Journal of Applied Ecology. 16(8), 1477-1481.

[4] Huang, J., Liu, S., Zhang, H., et al., 2016. Response of rice yield to double cropping rice-different winter green fertilizer rotation and environment. Ecology and Environmental Sciences. 25(8), 1271-1276.

[5] Gao, J., Huang, J., Yang, Z., et al., 2020. Plant Nutrition and Fertilizer Science. 26(3), 472-480. (in Chinese)

[6] Deng, L., Li, M., Fan, L., et al., 2018. Effect of green fertilizer rape on soil fertility and rice yield. Hunan Agricultural Sciences. (2), 18-20.

[7] Nanjing Agricultural College, 1980. Soil agrochemical analysis. Beijing: Agriculture Press.

[8] Zhou, J., Zhang, H., Yang, J., et al., 2020. Effects of continuous application of soil improver on soil fertility and active organic carbon components in sandy fluvial soil. Scientia Agricultura Sinica. 53(16), 3307-3318.

[9] Zhang, P., Zhong, C., Zhou, Q., et al., 2019. Chinese Journal of Eco-Agriculture. 27(8), 1163-1171. (in Chinese with English abstract)

[10] Feng, L., Wang, S., Yang, W., et al., 2020. Effects of maize and soybean intercropping patterns on agronomic traits and yield of soybean in red soil dryland. Soybean Science. 39(6), 882-890.

[11] Wang, Q., Bo, Y., Yu, K., et al., 2021. Effects of green fertilizer on rice ecosystem and its prospects. Soils. 53(2), 243-249. 
[12] Li, Z., Liu, M., Wu, X., et al., 2010. Effects of longterm chemical fertilization and organic amendments on dynamics of soil organic Cand total $\mathrm{N}$ in Soil and Tillage Research. 106(2), 268-274. (in Chinese)

[13] Zeng, Q., Gong, C., Xu, Y., et al., 2009. Effects of inverting pressure on yield and output value of Rice. Hunan Agricultural Sciences. 6, 76-77+88.

[14] He, R., Xue, Z., Wang, Y., et al., 2021. Analysis of economic and environmental benefits of returning rape straw to field and combining fertilizer application on rice. 42(6), 42-49.

[15] Li, P., Yang, B., Zhang, P., et al., 2020. Effects of mixed sowing of Chinese milk vex and rape on yield, Plant dry matter and nitrogen uptake and utilization of double cropping rice. Journal of Jiangxi Agricultural University. 42(2), 219-228.

[16] Zhao, R., Wang, Y., Su, G., et al., 2020. Effects of green fertilizer on soil chemical properties and fertilizer utilization rate. Journal of Tianjin Agricultural
College. 27(1), 92-97.

[17] Huang, G., 2008. Study on farmland Cycle Production technology in Jiangnan Hilly region i. Development of green fertilizer production in Jiangxi. Tillage and Cultivation. 2, 1-2 +12.

[18] Huang, J., Liao, Y., Lu, Y., et al., 2021. Effects of mixed sowing of Chinese milk vex and rape on green fertilizer and early rice yield. Hunan Agricultural Sciences. (6), 34-37+48.

[19] Cai, Z., 2020. Discussion on the development strategy of soil fertility and Soil Nutrient Cycle in the 14th Five-year Plan. Acta Pedologica Sinica. 57(5), 11281136.

[20] Zhang, W., Wang, S., Liu, B., et al., 2021. Effects of fertilizer and organic fertilizer application on soil fertility improvement in red paddy field based on soil fertility quality Comprehensive Index. Plant Nutrition and Fertilizer Science. 27(5), 777-790. 